\title{
KARAKTERISTIK UDANG KUPAS VANNAMEI \\ DENGAN PENAMBAHAN EDIBLE COATING BERBAHAN KITOSAN DAN EKSTRAK LINDUR (Bruguiera gymnorrhiza) SELAMA PENYIMPANAN
}

\section{Characterization of Peeled Vannamei Shrimp with Addition of Chitosan-based Edible Coating and Lindur (Bruguiera gymnorrhiza) Extract during Storage}

\author{
Ema Hastarini $i^{1^{*}}$, Indah Rosulva ${ }^{2}$, dan Yadi Haryadi ${ }^{3}$ \\ ${ }^{1}$ Balai Besar Penelitian dan Pengembangan Pengolahan Produk dan Bioteknologi Kelautan dan Perikanan, \\ Jl. K.S. Tubun Petamburan VI, Jakarta Pusat, Indonesia \\ ${ }^{2}$ Program studi Perikanan Universitas Tual, Indonesia \\ ${ }^{3}$ Program Pascasarjana Program Studi Ilmu Pangan IPB, Bogor, Indonesia \\ * Korespondensi Penulis: emahastarini@gmail.com
}

Diterima: 15 Agustus 2014; Disetujui: 26 November 2014

\begin{abstract}
ABSTRAK
Penggunaan edible coating merupakan salah satu cara yang dapat dilakukan untuk melindungi udang dari kerusakan selama penyimpanan, memperpanjang masa penyimpanan dan menjaga kualitas produk. Tujuan penelitian ini adalah untuk mengetahui pengaruh aplikasi edible coating dari campuran kitosan dan ekstrak lindur (Bruguiera gymnorrhiza) dalam mempertahankan mutu udang vannamei kupas selama penyimpanan pada suhu dingin. Perlakuan yang digunakan dalam penelitian ini adalah variasi konsentrasi bahan edible coating yaitu sebesar 0 dan $1 \%$ untuk kitosan dan 0, 1, dan 2\% untuk ekstrak lindur serta kombinasi antara keduanya. Parameter yang diuji dalam penelitian ini meliputi TVB, TPC, $\mathrm{pH}$, dan warna selama penyimpanan 1 , 4, dan 7 hari. Hasil penelitian menunjukkan bahwa perlakuan kitosan $0 \%$; lindur $2 \%$ mampu menghambat aktivitas bakteri,TVB, TPC, pH, dan warna udang vannamei kupas selama 1 minggu penyimpanan pada suhu $10{ }^{\circ} \mathrm{C}$ secara signifikan. Dengan demikian, ekstrak lindur dapat menjadi alternatif bahan antibakteri dan efektif sebagai pengawet alami pada udang vannamei kupas.
\end{abstract}

KATA KUNCl: edible coating, lindur (Bruguiera ghymnorhizza), kitosan, udang kupas, vannamei

\begin{abstract}
The use of edible coating is one method that could be done to protect the shrimp from the deterioration during storage, to extend the shelf life and maintain the quality of the product. The purpose of this study was to determine the effect of edible coating made from chitosan and extract lindur (Bruguiera gymnorrhiza) in maintaining quality vannamei shrimp peeled during storage at cold temperatures. The treatment used in this study is a variation of the concentration of the edible coating i.e. 0 and 1\% for chitosan; 0, 1 and 2\% for lindur extract and their combination. The parameters examined in this study included TVB, TPC, $p H$ and color during storage of 1, 4 and 7 days. The results showed that treatment of the mixture of chitosan $0 \%$ and lindur $2 \%$ was able to inhibit significantly the increase of TVB, TPC, $\mathrm{pH}$ and also maintan the color of the peeled vannamei shrimp after one week storage at $10^{\circ} \mathrm{C}$. Hence the extract lindur might be used as an alternative for antibacterial agent and a natural preservative of peeled vannamei shrimp.
\end{abstract}

KEYWORDS: edible coating, lindur (Bruguiera gymnorrhiza), chitosan, peeled off shrimp, vannamei

\section{PENDAHULUAN}

Udang vannamei (Litopenaeus vannamei) merupakan salah satu komoditi hasil perikanan yang banyak digemari oleh masyarakat. Udang telah diolah dalam berbagai variasi, diantaranya adalah dikeringkan, dibekukan dalam bentuk whole fresh (utuh), head-off tail on (tanpa kepala tetapi terdapat 
ekor), dan peeled (udang kupas). Pada umumnya udang kupas dijual di supermarket dan disajikan pada show case berpendingin yang suhunya belum mencukupi untuk mempertahankan mutu dengan penyimpanan yang lama. Hal yang menjadi permasalahan pada udang antara lain penurunan kualitas yang berlangsung cepat yang ditandai dengan perubahan warna, peningkatan volatile base nitrogen, perubahan tekstur dan keluarnya cairan yang mengandung padatan daging udang yang dikenal dengan istilah drip (Erdogdu, 2004). Mikroorganisme akan mengubah struktur protein daging selama penyimpanan dan akan menghasilkan bau yang tidak menyenangkan (Serdaroglu \& Felekoglu, 2005).

Dalam memperpanjang masa simpan dan menjaga kualitas produk dapat digunakan edible coating (Kilincceker, 2009). Edible coating adalah lapisan tipis yang bertujuan untukmemperpanjang umur simpan dan mempertahankan mutu selama penyimpanan. Edible coating dapat dibuat dari tiga jenis bahan yang berbeda yaitu hidrokoloid (protein dan polisakarida), lipida, dan komposit (Krochta et al., 1994). Bahanbahan yang paling sering digunakan dalam memproduksi edible coatings adalah polimer alam seperti kitosan. Kitosan merupakan turunan dari kitin yang berasal dari cangkang udang atau rajungan yang mengandung $20-30 \%$ senyawa kitin, $21 \%$ protein dan 40-50\% mineral. Kitosan merupakan polisakarida terbesar ke dua setelah selulosa yang mempunyai rumus kimia poli (2-amino-2-dioksi-â-D-Glukosa) yang dapat dihasilkan dengan proses hidrolisis kitin menggunakan basa atau asam kuat (Hargono et al., 2008). Kitosan sebagai edible coating memiliki sifat mekanik yang memadai dan sifat penghalang gas yang baik (oksigen dan aroma) (Abugoch,2011) dan bersifat biodegradable (López-Caballero et al., 2005; Bourtoom et al., 2008; Bourbonet al, 2011). Walaupun kitosan memiliki sifat-sifat yang diperlukan sebagai bahan dasar edible coating, tetapi perlu dilakukan penambahan senyawa lain selain kitosan untuk meningkatkan kualitasnya sebagai pelapis alami pada produk pangan. Lindur (Bruguiera gymnorrhiza) merupakan salah satu alternatif sebagai bahan edible coating yang dapat ditambahkan pada produk karena memiliki efek mengawetkan dan memiliki sifat antibakteri.

Buah lindur merupakan salah satu buah bakau yang mengandung komponen bioaktif yang tinggi seperti steroid, triterpen, saponin, flavonoid, alkaloid dan tanin sehingga dapat juga digunakan untuk mengawetkan produk perikanan dan dapat bersifat sebagai sumber antimikroba alami (Sivaperumal et al., 2010). Lindur belum banyak dimanfaatkan oleh masyarakat dan umumnya hanya digunakan sebagai campuran pada makanan ringan. Aplikasi ekstrak lindur dalam pembuatan edible coating diharapkan dapat berperan dalam industri pangan sebagai biodegradable film untuk menggantikan polimer plastik dengan harga ekonomis, dapat diperbaharui dan memberikan sifat antimikroba yang baik sehingga bisa menunjang bahan edible coating lainnya untuk menghasilkan kualitas yang lebih baik. Hasil penelitian sebelumnya menunjukkan bahwa penggunaan lindur sebesar $2 \%$ sebagai edible coating mampu memperpanjang masa simpan udang kupas black tiger dibandingkan dengan kontrol (tanpa edible coating) (Rosulva et al., 2014). Berdasarkan hasil penelitian tersebut maka perlu dilakukan penelitian edible coating berbahan kitosan dan lindur pada komoditi udang yang berbeda yaitu jenis udang vannamei dengan variasi waktu penyimpanan.

Tujuan penelitian ini adalah mengetahui pengaruh aplikasi edible coating berbahan kitosan dan ekstrak lindur (Bruguiera gymnorrhiza) dalam mempertahankan mutu udang vannamei kupas selama penyimpanan pada suhu dingin.

\section{BAHAN DAN METODE}

\section{Bahan}

Bahan yang digunakan dalam penelitian ini adalah udang jenis vannamei (Litopenaeus vannamei) yang diperoleh dariperusahaan Everfresh di Jakarta, buah bakau jenis lindur (Bruguiera gymnorrhiza) yang diperoleh dari daerah bakau di sekitar kepulauan Kei, Maluku Tenggara, dan kitosan yang diperoleh dari perusahaan Biotech Surindo di Cirebon.

\section{Metode}

Metode penelitian ini meliputi pembuatan tepung buah lindur, pembuatan ekstrak dari tepung lindur, serta aplikasi edible coating berbasis campuran kitosan dan ekstrak lindur pada udang kupas. Parameter yang diamati meliputi TVB (AOAC, 1995), derajat keasaman $(\mathrm{pH})$ dengan metode AOAC (2006), TPC (Fardiaz, 1993) dan warna (Hutching, 1999) menggunakan alat Hunter Lab Chromameter Color Flex EZ. Pengamatan dilakukan selama 1, 4, dan 7 hari penyimpanan pada suhu $10^{\circ} \mathrm{C}$ dengan ulangan sebanyak 3 kali.

\section{Pembuatan tepung dari buah lindur}

Buah lindur dikupas kulitnya dan direndam dalam air beberapa kali hingga air rendaman bening, selanjutnya direbus selama 60 menit. Setelah proses perebusan, buah lindur dihancurkan dan dijemur hingga kering selanjutnya dihaluskan hingga berukuran 
65 mesh. Prosedur pembuatan tepung lindur dapat dilihat pada Gambar 1.

\section{Pembuatan Ekstrak Lindur dari Tepung Lindur}

Ekstraksi sampel dilakukan dengan metode maserasi menurut metode Malangngi et al.(2012). Sebanyak $20 \mathrm{~g}$ sampel direndam dalam $100 \mathrm{ml}$ etanol 95\% selama 24 jam kemudian disaring sehingga diperoleh filtrat (filtrat pertama). Sisa padatan diperlakukan sama guna mendapatkan filtrat kedua. Kedua filtrat yang diperoleh disatukan, kemudian diuapkan menggunakan rotavapor sehingga diperoleh ekstrak lindur. Penimbangan dilakukan terhadap labu kosong sebagai bobot awal dan labu berisi ekstrak. Bobot filtrat dihitung dari selisih bobot akhir setelah evaporasi dengan bobot awal labu kosong. Ekstrak hasil evaporasi dalam labu kemudian dilarutkan dalam $10 \mathrm{ml}$ etanol. Sisa ekstrak yang menempel dalam labu dilarutkan dengan bantuan sonikator. Ekstrak yang didapat kemudian didinginkan dalam desikator sebelum analisis lebih lanjut.

\section{Aplikasi Edible Coating pada Udang Kupas}

Pada penelitian ini digunakan larutan kitosan dengan konsentrasi 0 dan $1 \%$ terhadap asam asetat $1 \%$ sebagai pelarut (b/v), serta konsentrasi ekstrak lindur sebanyak 0,1 , dan $2 \%$ dengan etanol sebagai pelarut ( $(\mathrm{v} / \mathrm{v})$,kemudian dikombinasikan menjadi campuran kitosan-ekstrak lindur sebagai perlakuan (Tabel 1).

Campuran dari masing-masing perlakuan dilarutkan dalam air destilata sebanyak $500 \mathrm{ml}$, dilakukan penambahan agar $1 \%(\mathrm{~b} / \mathrm{v})$ dan gliserol $0.5 \%$ (v/v) kemudian dipanaskan hingga mendidih. Larutan kemudian didinginkan hingga suhu sekitar $40^{\circ} \mathrm{C}$. Setelah itu, larutan diaplikasikan sebagai edible coating dengan cara mencelupkan udang kupas selama 5 detik. Udang kupas yang telah dilapisi edible coating kemudian ditiriskan pada suhu kamar sampai lapisan edible coating mengering. Udang kupas kemudian disimpan pada suhu dingin $\left(10^{\circ} \mathrm{C}\right)$. Diagram alir prosedur aplikasi edible coating pada udang kupas dapat dilihat pada Gambar 2.

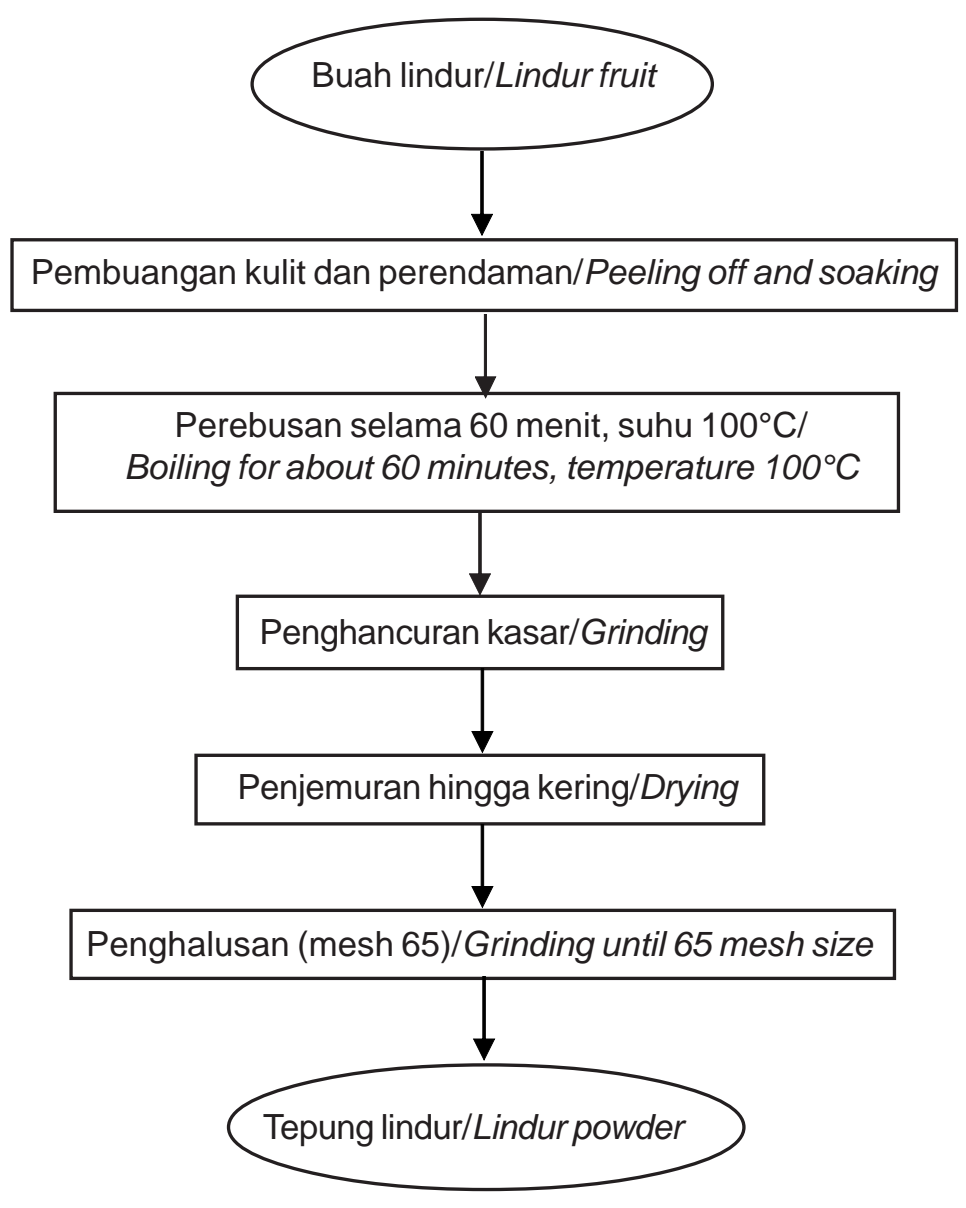

Gambar 1. Diagram alir pembuatan tepung lindur.

Figure 1. Flow chart of lindur powder processing. 
Tabel 1. Kombinasi campuran kitosan-ekstrak lindur sebagai bahan edible coating Table1. Combination of chitosan-lindur extract mixture as edible coating material

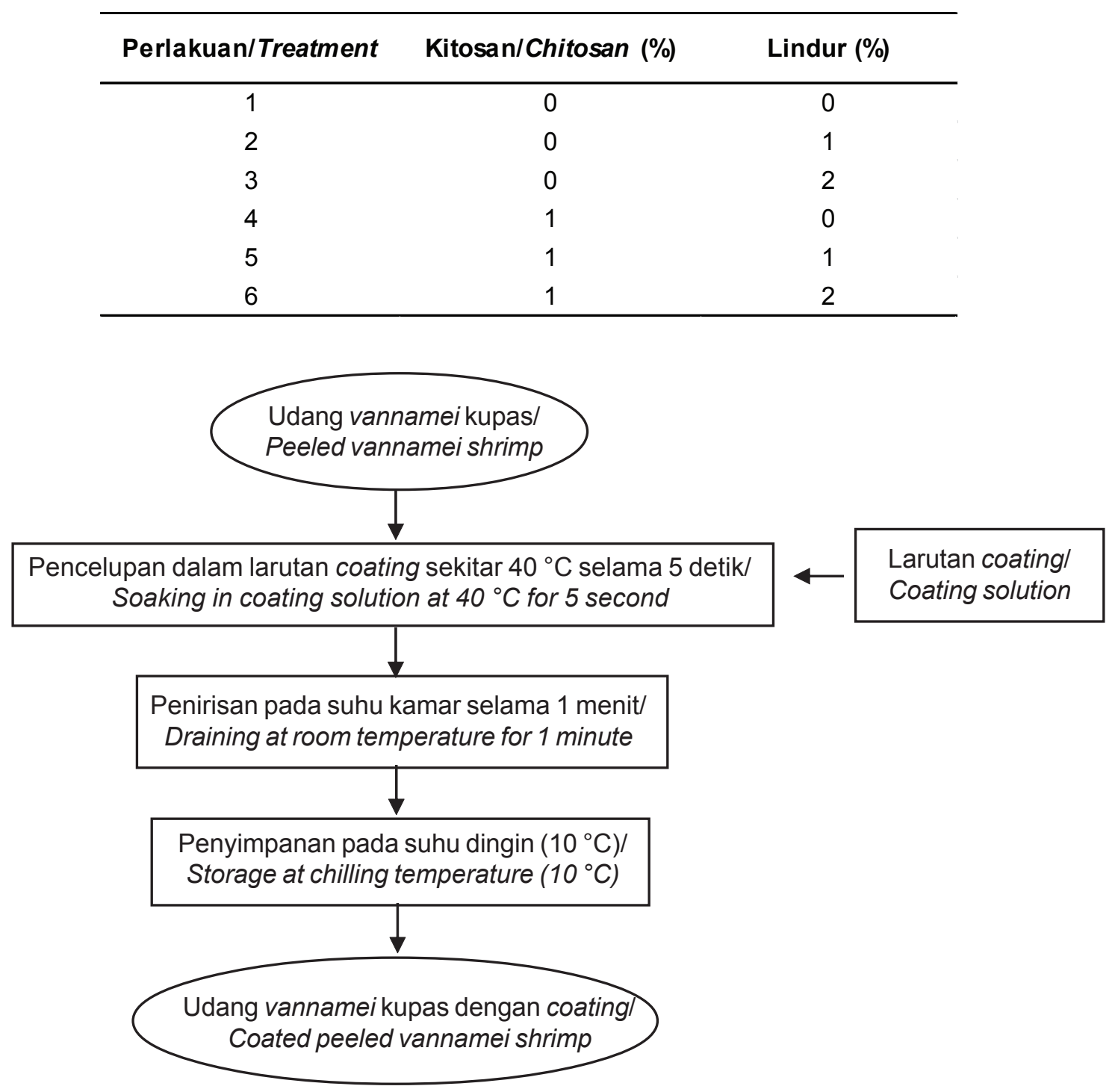

Gambar 2. Diagram alir prosedur aplikasi edible coating kitosan-ekstrak lindur.

Figure 2. Flow chart of application procedure of edible coating based chitosan and lindur extract.

Pengambilan sampel dilakukan setiap 1, 4 dan 7 hari penyimpanan untuk dilakukan analisis terhadap TVB (AOAC, 1995), TPC (Fardiaz, 1993), pH (AOAC, 2006) dan warna produk (Hucthing, 1999). Analisa warna dilakukan menggunakan alat Hunter Lab dengan konotasi warna $L^{*}, a^{*}$ dan $b^{*}$. Nilai $L^{*}$ menunjukkan pengukuran tingkat kecerahan, yang dinyatakan sebagai cahaya pantul yang menghasilkan warna akromatik putih, abu-abu dan hitam. Nilai L* berkisar dari 0 (hitam) hingga 100 (putih).Nilai a* menentukan warna kromatik campuran merah-hijau di dalam sampel. Nilai a+ (positif) dari 0 sampai +80 untuk warna merah dan a- (negatif) dari 0 sampai -80 untuk warna hijau.Nilai $b^{*}$ menentukan warna kromatik gradasi kuning-biru. Nilai $b+$ (positif) dari 0 sampai +70 untuk warna kuning dan b- (negatif) dari 0 sampai -70 untuk warna biru.

\section{HASIL DAN PEMBAHASAN}

\section{Kadar Total Volatile Base (TVB)}

Hasil analisis ragam menunjukkan bahwa terdapat perbedaan nilai TVB yang nyata pada keenam perlakuan pada penyimpanan 1,4 , dan 7 hari $(p<0,05)$. Nilai TVB udang kupas yang diperoleh 
selama pengamatan cukup tinggi. Hal ini berkaitan dengan kesegaran/mutu udang yang digunakan. Pada awalnya udang yang digunakan sangat segar dengan nilai TVB 3,97 mgN/100 g. Nilai ini sesuai dibandingkan dengan standar TVB ikan segar, yakni $<10 \mathrm{mgN} / 100 \mathrm{~g}$ bahan. Namun, seiring dengan berjalannya proses penyimpanan dengan suhu \pm 10 ${ }^{\circ} \mathrm{C}$ mengakibatkan peningkatan proses autolisis dan aktivitas bakteri pembusuk yang meningkatkan nilai TVB hingga ikan tidak layak konsumsi setelah penyimpanan 7 hari (TVB > $30 \mathrm{mgN} / 100 \mathrm{~g}$ ). Perubahan TVB udang kupas selama penyimpanan dapat dilihat pada Tabel 2.

Nilai TVB udang kupas mengalami peningkatan seiring dengan lamanya waktu penyimpanan. Peningkatan nilai TVB udang selama penyimpanan diakibatkan adanya degradasi protein atau turunannya, menghasilkan sejumlah basa yang mudah menguap seperti amoniak, histamin, hidrogen sulfida dan trimetilamin (Suptijah et al., 2007). Menurut Songsaeng et al. (2010) peningkatan nilai TVB merupakan akibat dari pertumbuhan mikroba yang semakin cepat yang terlibat dalam produksi basa volatil. Namun perlakuan dengan edible coating terbukti mampu melindungi produk dari terbentuknya basa volatil yang tidak diinginkan. Hal ini terbukti bahwa perlakuan kontrol (tanpa penambahan edible coating) memiliki nilai TVB yang paling tinggi dan berbeda nyata dengan perlakuan lainnya.

Pada penyimpanan 1 dan 4 hari, kitosan dan ekstrak lindur berpengaruh nyata terhadap nilai TVB $(p<0,05)$. Uji lanjut Duncan menunjukkan bahwa kadar TVB udang yang diberi perlakuan ekstrak lindur dan kitosan secara nyata lebih rendah dari kadar TVB udang kontrol. Pada penyimpanan hingga 7 hari didapatkan bahwa perlakuan kitosan dan ekstrak lindur dan interaksinya berpengaruh nyata terhadap nilai TVB $(p<0,05)$. Perlakuan penambahan ekstrak lindur $2 \%$ tanpa kitosan terbukti dapat mempertahankan kesegaran udang sehingga masih layak untuk dikonsumsi setelah disimpan pada suhu $10^{\circ} \mathrm{C}$ selama 7 hari. Hal ini diduga karena adanya kandungan fenolik dalam ekstrak lindur yang terbukti dapat menghambat mikroba dan mencegah terbentuknya basa volatil dalam tubuh ikan.

\section{Derajat Keasaman (pH)}

Hasil analisis ragam menunjukkan bahwa terdapat perbedaan nilai $\mathrm{pH}$ yang nyata pada keenam perlakuan pada 1 , 4, dan 7 hari penyimpanan $(p<0,05)$. Nilai $\mathrm{pH}$ awal dari udang segar sebesar 7,06. Perubahan nilai $\mathrm{pH}$ udang kupas selama penyimpanan dapat dilihat pada Tabel 3.

Perlakuan penambahan ekstrak lindur diduga bersifat asam sehingga dapat menurunkan nilai $\mathrm{pH}$, sedangkan penambahan kitosan dapat meningkatkan $\mathrm{pH}$ produk menjadi lebih basa karena kitosan mengandung banyak gugus amin yang bersifat basa. Uji lanjut Duncan menunjukkan bahwa nilai pH udang yang diberi perlakuan kitosan dan ekstrak lindur secara nyata lebih rendah dari nilai pH udang kontrol. Pada penyimpanan hingga 7 hari didapatkan bahwa perlakuan kitosan dan ekstrak lindur dan interaksinya berpengaruh nyata terhadap jumlah TPC $(p<0,05)$.

Derajat keasaman atau $\mathrm{pH}$ mempengaruhi kekuatan gel agar yang membentuk edible coating. Kekuatan gel tinggi apabila $\mathrm{pH}$ berkisar antara 6-7

Tabel 2. Nilai total volatile base (TVB) udang kupas selama penyimpanan

Table 2. Total volatile base (TVB) value of peeled shrimp during storage

\begin{tabular}{|c|c|c|c|c|}
\hline \multicolumn{2}{|c|}{ Perlakuan/Treatment } & \multicolumn{3}{|c|}{ TVB Selama Penyimpanan/TVB Value During Storage } \\
\hline $\begin{array}{c}\text { Kitosan/Chitosan } \\
\text { (\%) (b/v) }\end{array}$ & $\begin{array}{l}\text { Lindur } \\
\text { (\%) (v/v) }\end{array}$ & 1 hari/day & 4 harilday & 7 harilday \\
\hline \multirow{3}{*}{0} & 0 & $15.99 \pm 0.007^{c}$ & $46.82 \pm 1.676^{d}$ & $64.91 \pm 0.014^{f}$ \\
\hline & 1 & $11.29 \pm 0.007^{b}$ & $20.94 \pm 1.329^{b}$ & $44.23 \pm 1.103^{c}$ \\
\hline & 2 & $15.76 \pm 0.339^{c}$ & $18.35 \pm 0.007^{\mathrm{a}}$ & $19.73 \pm 0.042^{a}$ \\
\hline \multirow{3}{*}{1} & 0 & $21.18 \pm 0.021^{c}$ & $56.21 \pm 0.297^{c}$ & $62.53 \pm 0.042^{c}$ \\
\hline & 1 & $17.88 \pm 0.169^{d}$ & $32.93 \pm 0.007^{c}$ & $47.98 \pm 1.443^{d}$ \\
\hline & 2 & $10.81 \pm 0.014^{a}$ & $18.35 \pm 0.007^{a}$ & $25.06 \pm 0.085^{b}$ \\
\hline
\end{tabular}

Keterangan/Note: Pada tiap kolom, nilai TVB yang diikuti huruf yang sama, tidak berbeda nyata satu sama lain (Uji Duncan pada $p=0,05$ )/In each column, TVB value with the same alphabet, were found to be significance level $(p=0.05)$ 
Tabel 3. Nilai $p H$ udang kupas selama penyimpanan

Table 3. $\mathrm{pH}$ value of peeled shrimp during storage

\begin{tabular}{ccccc}
\hline \multicolumn{2}{c}{ Perlakuan/Treatment } & \multicolumn{4}{c}{ Nilai pH Selama Penyimpanan/pH Value During Storage } \\
\hline $\begin{array}{c}\text { Kitosan/Chitosan } \\
\text { (\%) (b/v) }\end{array}$ & $\begin{array}{c}\text { Lindur } \\
\text { (\%) (v/v) }\end{array}$ & 1 hari/day & 4 hari/day & 7 hari/day \\
\hline & 0 & $7.03 \pm 0.008^{\mathrm{e}}$ & $7.20 \pm 0.013^{\mathrm{f}}$ & $7.25 \pm 0.011^{\mathrm{f}}$ \\
0 & 1 & $6.83 \pm 0.008^{\mathrm{b}}$ & $6.88 \pm 0.008^{\mathrm{c}}$ & $6.86 \pm 0.005^{\mathrm{b}}$ \\
& 2 & $6.74 \pm 0.005^{\mathrm{a}}$ & $6.93 \pm 0.005^{\mathrm{d}}$ & $6.84 \pm 0.005^{\mathrm{a}}$ \\
\hline \multirow{2}{*}{1} & 0 & $6.89 \pm 0.008^{\mathrm{d}}$ & $6.70 \pm 0.013^{\mathrm{b}}$ & $7.00 \pm 0.011^{\mathrm{e}}$ \\
& 1 & $6.84 \pm 0.005^{\mathrm{c}}$ & $6.95 \pm 0.008^{\mathrm{e}}$ & $6.96 \pm 0.005^{\mathrm{c}}$ \\
& 2 & $6.89 \pm 0.008^{\mathrm{d}}$ & $6.48 \pm 0.004^{\mathrm{a}}$ & $6.99 \pm 0.005^{\mathrm{d}}$ \\
\hline
\end{tabular}

Keterangan/Note: Pada tiap kolom, nilai $\mathrm{pH}$ yang diikuti huruf yang sama, tidak berbeda nyata satu sama lain (Uji Duncan pada $\mathrm{p}=0,05) / I n$ each column, $\mathrm{pH}$ value with the same alphabet, were found to be significance level $(p=0.05)$

karena protein miosin mudah larut pada $\mathrm{pH}$ tersebut. Di luar kisaran $\mathrm{pH}$ tersebut baik asam atau basa, kekuatan gel akan lebih rendah atau turun. Nilai $\mathrm{pH}$ lebih dari 7 dapat melemahkan gel karena terjadi hidrasi protein, sedangkan $\mathrm{pH}$ kurang dari 6 menyebabkan ketidakstabilan protein miofibril dalam daging dan mengindikasikan penurunan kemampuan pembentukan gel (Babji \& Kee, 1994). Berdasarkan hal tersebut, udang kupas yang dilapisi edible coating menunjukkan perubahan $\mathrm{pH}$ yang lebih lambat karena udang terlindungi edible coating dengan gel yang stabil, sehingga proses degradasi protein menjadi lambat. Degradasi protein akan menghasilkan senyawa-senyawa nitrogen yang lebih sederhana, diantaranya yaitu asam amino bebas dan basa nitrogen yang menyebabkan terjadinya proses autolisis maupun kerusakan secara mikrobiologis. Hal ini terbukti bahwa dengan perlakuan kontrol berbeda nyata dengan perlakuan lainnya dan memiliki nilai $\mathrm{pH}$ yang paling tinggi. Perlakuan penambahan ekstrak lindur $2 \%$ tanpa kitosan terbukti paling optimal dalam menekan peningkatan nilai $\mathrm{pH}$.

\section{Kadar Total Plate Count (TPC)}

Hasil analisis ragam menunjukkan bahwa perlakuan kitosan dan ekstrak lindur serta

Tabel 4. Nilai total plate count (TPC) udang kupas selama penyimpanan

Table 4. Total plate count (TPC) value of peeled shrimp during storage

\begin{tabular}{ccccc}
\hline \multicolumn{2}{c}{ Perlakuan/Treatment } & \multicolumn{2}{c}{$\begin{array}{c}\text { Nilai TPC (unit koloni/g) Selama Penyimpanan/ } \\
\text { TPC Value (coloni unit/g) During Storage }\end{array}$} \\
\hline $\begin{array}{c}\text { Kitosan/Chitosan } \\
\text { (\%) (b/v) }\end{array}$ & $\begin{array}{c}\text { Lindur } \\
(\%)(\mathbf{v} / \mathrm{v})\end{array}$ & $\mathbf{1}$ hari/day & $\mathbf{4}$ hari/day & $\mathbf{7}$ hari/day \\
\hline & 0 & $1.07 \times 10^{5} \pm 0.02^{\mathrm{d}}$ & $6.18 \times 10^{5} \pm 0.27^{\mathrm{f}}$ & $7.94 \times 10^{5} \pm 0.09^{\mathrm{c}}$ \\
0 & 1 & $5.78 \times 10^{3} \pm 0.36^{\mathrm{c}}$ & $6.45 \times 10^{4} \pm 0.07^{\mathrm{e}}$ & $1.02 \times 10^{5} \pm 0.01^{\mathrm{a}}$ \\
& 2 & $1.83 \times 10^{3} \pm 0.14^{\mathrm{e}}$ & $5.50 \times 10^{3} \pm 0.18^{\mathrm{c}}$ & $1.29 \times 10^{5} \pm 0.04^{\mathrm{b}}$ \\
\hline & 0 & $1.12 \times 10^{4} \pm 0.05^{\mathrm{a}}$ & $7.09 \times 10^{3} \pm 0.31^{\mathrm{a}}$ & $6.92 \times 10^{5} \pm 0.15^{\mathrm{d}}$ \\
& 1 & $3.74 \times 10^{3} \pm 0.25^{\mathrm{b}}$ & $3.80 \times 10^{4} \pm 0.04^{\mathrm{b}}$ & $1.80 \times 10^{5} \pm 0.04^{\mathrm{a}}$ \\
& 2 & $3.64 \times 10^{3} \pm 0.15^{\mathrm{b}}$ & $7.78 \times 10^{3} \pm 0.34^{\mathrm{a}}$ & $6.31 \times 10^{5} \pm 0.07^{\mathrm{d}}$ \\
\hline
\end{tabular}

Keterangan/Note: Pada tiap kolom, nilai TPC yang diikuti huruf yang sama, tidak berbeda nyata satu sama lain (Uji Duncan pada $p=0,05)$ / In each column, TPC value with the same alphabet, were found to be significance level $(p=0.05)$ 
interaksinya berpengaruh nyata terhadap nilai TPC pada 1,4 , dan 7 hari penyimpanan $(p<0,05)$. TPC pada awal penyimpanan sebesar $3,1 \times 10^{3}$ atau setara dengan 3,49 log cfu/g. Hasil analisis menunjukkan bahwa nilai TPC udang selama penyimpanan berkisar antara 1,83 × $10^{3}$ sampai 7,94 × $10^{5}$ unit koloni/g. Badan Standarisasi Nasional menetapkan ALT maksimal yang diperbolehkan untuk udang segar sebesar $5 \mathrm{x}$ $10^{5}$ unit koloni/g atau setara dengan 5,69 log cfu/g (BSN, 2006). Nilai TPC udang selama penyimpanan dapat dilihat pada Tabel 4.

Udang kupas tanpa pemberian coating (kontrol) akan lebih mudah mengalami kontaminasi mikrobiologi dari lingkungannya sehingga kandungan bakteri pada produk tersebut lebih tinggi dibandingkan dengan produk yang dicoating. Berdasarkan nilai TPC dapat dikatakan bahwa jumlah mikroorganisme cenderung semakin meningkat dengan lamanya penyimpanan.

Uji lanjut Duncan menunjukkan bahwa jumlah TPC udang yang diberi perlakuan kitosan dan ekstrak lindur secara nyata lebih rendah dari jumlah TPC udang kontrol terutama pada penyimpanan 1 dan 4 hari. Pada penyimpanan hingga 7 hari didapatkan bahwa perlakuan kitosan dan ekstrak lindur dan interaksinya berpengaruh nyata terhadap jumlah TPC $(p<0,05)$. Perlakuan penambahan ekstrak lindur $2 \%$ tanpa kitosan terbukti dapat menekan pertumbuhan mikroba dalam tubuh ikan sehingga dapat mempertahankan kesegaran udang. Ekstrak lindur mengandung komponen antimikroba dari senyawa fenolik (Sivaperumal et al., 2010). Senyawa fenolik merupakan komponen antimikroba utama di dalam minyak esensial tanaman. Selain itu, lapisan coating pada permukaan produk udang kupas diduga dapat juga berfungsi sebagai barrier atau penghalang masuknya mikroba dari luar produk. Penggunaan edible coating yang dikombinasikan dengan komponen bioaktif dapat memperpanjang masa simpan produk yang mudah mengalami kerusakan (highly perishable product) (Bourbon et al., 2011).

\section{Warna}

Perubahan warna produk diamati berdasarkan prinsip pengukuran warna yang dipantulkan dari permukaan sampel. Hasil pengukuran chromameter dikonversikan ke dalam sistem Hunter dengan lambang $L^{*}, a^{*}$, dan $b^{*}$. Berdasarkan hasil analisis terhadap warna terlihat bahwa nilai warna $L^{*}$ udang kupas selama penyimpanan berkisar antara 41,7148,85 yang menunjukkan terjadi perubahan warna dari putih cerah menjadi agak kusam. Nilai warna $a^{*}$ berkisar antara 7,41-11,68 dan nilai warna $b *$ berkisar antara 6,86-13,05.

Nilai $L^{*}$ menunjukkan pengukuran tingkat kecerahan dan dinyatakan sebagai cahaya pantul yang menghasilkan warna akromatik putih, abu-abu dan hitam. Nilai L* berkisar dari 0 (hitam) hingga 100 (putih). Nilai $L^{*}$ pada udang kupas yang diberi penambahan kitosan dan ekstrak lindur cenderung mengalami peningkatan dengan semakin meningkatnya konsentrasi kitosan dan ekstrak lindur yang ditambahkan ke dalam edible coating. Hal ini disebabkan karena edible coating yang terbentuk memiliki sifat gel yang stabil, dan pada saat diaplikasikan pada udang kupas mampu menyelimuti permukaan dengan sempurna sehingga udang menjadi mengkilap dan cerah selama penyimpanan. Selain itu, tingginya kecerahan pada produk juga disebabkan

Tabel 5. Nilai L* udang kupas selama penyimpanan

Table 5. $L *$ value of peeled shrimp during storage

\begin{tabular}{ccccc}
\hline \multicolumn{2}{c}{ Perlakuan/Treatment } & \multicolumn{3}{c}{ Penyimpanan/Storage } \\
\hline $\begin{array}{c}\text { Kitosan/Chitosan } \\
\text { (\%) (b/v) }\end{array}$ & $\begin{array}{c}\text { Lindur } \\
(\%)(v / v)\end{array}$ & 1 hari/day & 4 hari/day & 7 hari/day \\
\hline 0 & 0 & $43.64 \pm 0.01^{\mathrm{a}}$ & $41.60 \pm 0.04^{\mathrm{a}}$ & $43.62 \pm 0.02^{\mathrm{b}}$ \\
& 1 & $45.71 \pm 0.03^{\mathrm{b}}$ & $41.71 \pm 0.03^{\mathrm{b}}$ & $48.17 \pm 0.02^{\mathrm{d}}$ \\
& 2 & $46.97 \pm 0.03^{\mathrm{c}}$ & $46.00 \pm 0.02^{\mathrm{c}}$ & $47.96 \pm 0.03^{\mathrm{c}}$ \\
\hline & 0 & $48.28 \pm 0.04^{\mathrm{d}}$ & $53.81 \pm 0.01^{\mathrm{f}}$ & $42.34 \pm 0.01^{\mathrm{a}}$ \\
& 1 & $48.66 \pm 0.01^{\mathrm{e}}$ & $47.55 \pm 0.00^{\mathrm{d}}$ & $48.67 \pm 0.03^{\mathrm{e}}$ \\
& 2 & $48.85 \pm 0.04^{\mathrm{f}}$ & $50.37 \pm 0.05^{\mathrm{e}}$ & $48.18 \pm 0.04^{\mathrm{d}}$ \\
\hline
\end{tabular}

Keterangan/Note: Pada tiap kolom, nilai $L^{*}$ yang diikuti huruf yang sama, tidak berbeda nyata satu sama lain (Uji Duncan pada $p=0.05) /$ In each column, $L^{*}$ value with the same alphabet, were found to be significance level $(p=0.05)$ 
karena kitosan dan ekstrak lindur mampu menjaga perubahan oksidasi pada udang kupas sehingga udang tetap cerah dan putih selama penyimpanan. Hasil analisis ragam menunjukkan bahwa konsentrasi kitosan dan ekstrak lindur memberikan perbedaan nyata $(p<0,05)$ terhadap nilai $L^{*}$ udang kupas selama penyimpanan. Uji lanjut Duncan menunjukkan pengaruh nyata antar keenam perlakuan. Perubahan warna daging udang selama penyimpanan dapat dilihat pada Tabel 5, 6, dan 7 .
Nilai warna $a^{*}$ menentukan warna kromatik campuran merah-hijau di dalam sampel. Nilai a+ (positif) dari 0 sampai +80 untuk warna merah dan a(negatif) dari 0 sampai -80 untuk warna hijau. Hasil analisis ragam menunjukkan bahwa konsentrasi kitosan dan ekstrak lindur memberikan perbedaan nyata $(p<0.05)$ terhadap nilai warna $a^{*}$ udang kupas selama penyimpanan. Uji lanjut Duncan menunjukkan pengaruh nyata antara keenam perlakuan. Semakin tinggi nilai $a^{*}$ menunjukkan bahwa udang semakin

Tabel 6. Nilai $a^{\star}$ udang kupas selama penyimpanan

Table 6. $a^{*}$ value of peeled shrimp during storage

\begin{tabular}{ccccc}
\hline \multicolumn{2}{c}{ Perlakuan/Treatment } & \multicolumn{3}{c}{ Penyimpanan/Storage } \\
\hline $\begin{array}{c}\text { Kitosan/Chitosan } \\
(\%)(b / v)\end{array}$ & $\begin{array}{c}\text { Lindur } \\
(\%)(v / v)\end{array}$ & 1 harilday & 4 hari/day & 7 hari/day \\
\hline & 0 & $11.47 \pm 0.01^{\mathrm{e}}$ & $8.06 \pm 0.02^{\mathrm{e}}$ & $10.12 \pm 0.04^{\mathrm{f}}$ \\
0 & 1 & $11.01 \pm 0.02^{\mathrm{d}}$ & $8.56 \pm 0.01^{\mathrm{f}}$ & $7.64 \pm 0.02^{\mathrm{a}}$ \\
& 2 & $11.68 \pm 0.01^{\mathrm{f}}$ & $7.41 \pm 0.01^{\mathrm{a}}$ & $9.13 \pm 0.02^{\mathrm{e}}$ \\
\hline & 0 & $7.42 \pm 0.01^{\mathrm{a}}$ & $8.06 \pm 0.00^{\mathrm{c}}$ & $8.99 \pm 0.02^{\mathrm{d}}$ \\
1 & 1 & $8.57 \pm 0.02^{\mathrm{b}}$ & $7.87 \pm 0.01^{\mathrm{b}}$ & $8.2 \pm 0.02^{\mathrm{b}}$ \\
& 2 & $8.70 \pm 0.02^{\mathrm{c}}$ & $8.11 \pm 0.01^{\mathrm{d}}$ & $8.91 \pm 0.02^{\mathrm{c}}$ \\
\hline
\end{tabular}

Keterangan/Note: Pada tiap kolom, nilai $a^{\star}$ yang diikuti huruf yang sama, tidak berbeda nyata satu sama lain (Uji Duncan pada $\mathrm{p}=0.05) / / n$ each column, $a^{*}$ value with the same alphabet, were found to be significance level $(p=0.05)$

Tabel 7. Nilai $b^{\star}$ udang kupas selama penyimpanan

Table 7. $b^{\star}$ value of peeled shrimp during storage

\begin{tabular}{|c|c|c|c|c|}
\hline \multicolumn{2}{|c|}{ Perlakuan/Treatment } & \multicolumn{3}{|c|}{ Penyimpanan/Storage } \\
\hline $\begin{array}{c}\text { Kitosan/Chitosan } \\
\text { (\%) (b/v) }\end{array}$ & $\begin{array}{l}\text { Lindur } \\
(\%)(v / v)\end{array}$ & 1 harilday & 4 hari/day & 7 harilday \\
\hline \multirow{3}{*}{0} & 0 & $13.05 \pm 0.05^{f}$ & $8.08 \pm 0.02^{\mathrm{e}}$ & $12.88 \pm 0.03^{d}$ \\
\hline & 1 & $12.31 \pm 0.01^{\mathrm{e}}$ & $7.54 \pm 0.02^{d}$ & $9.83 \pm 0.01^{a}$ \\
\hline & 2 & $12.00 \pm 0.01^{d}$ & $7.09 \pm 0.03^{b}$ & $10.89 \pm 0.01^{b}$ \\
\hline \multirow{3}{*}{1} & 0 & $9.75 \pm 0.00^{a}$ & $6.86 \pm 0.05^{a}$ & $10.97 \pm 0.03^{c}$ \\
\hline & 1 & $10.02 \pm 0.01^{\mathrm{c}}$ & $7.29 \pm 0.02^{\mathrm{c}}$ & $9.83 \pm 0.00^{\mathrm{a}}$ \\
\hline & 2 & $9.90 \pm 0.00^{b}$ & $7.26 \pm 0.04^{c}$ & $10.86 \pm 0.00^{b}$ \\
\hline
\end{tabular}

Keterangan/Note: Pada tiap kolom, nilai $b^{*}$ yang diikuti huruf yang sama, tidak berbeda nyata satu sama lain (Uji Duncan pada $p=0.05) /$ In each column, $b^{*}$ value with the same alphabet, were found to be significance level $(p=0.05)$ 
merah yang berarti telah terjadi perubahan warna secara enzimatis akibat proses oksidasi dalam tubuh udang. Udang tanpa diberi perlakuan (kontrol) mengalami perubahan warna yang paling tinggi dibandingkan dengan udang yang diberi penambahan kitosan dan ekstrak lindur.

Nilai warna b* menentukan warna kromatik gradasi kuning-biru. Nilai b+ (positif) dari 0 sampai +70 untuk warna kuning dan b- (negatif) dari 0 sampai -70 untuk warna biru. Hasil analisis ragam menunjukkan bahwa konsentrasi kitosan dan ekstrak lindur memberikan perbedaan nyata $(p<0,05)$ terhadap nilai warna $b *$ udang kupas selama penyimpanan. Uji lanjut Duncan menunjukkan pengaruh nyata antar keenam perlakuan. Semakin tinggi nilai b* menunjukkan bahwa udang semakin kuning yang berarti telah terjadi perubahan warna secara enzimatis akibat proses oksidasi dalam tubuh udang. Udang tanpa diberi perlakuan (kontrol) mengalami perubahan warna yang paling tinggi dibandingkan dengan udang yang diberi penambahan kitosan dan ekstrak lindur.

\section{KESIMPULAN}

Pada percobaan dengan udang vannamei, edible coating berbahan ekstrak lindur 2\% tanpa kitosan secara nyata mampu menurunkan nilai TVB, pH dan TPC udang kupas dibandingkan dengan kontrol pada penyimpanan $10^{\circ} \mathrm{C}$ selama 7 hari. Berdasarkan nilai warna $L^{*}, a^{*}$, dan $b^{*}$ perubahan warna pada udang kupas selama penyimpanan dapat dihambat untuk semua perlakuan kecuali kontrol. Ekstrak lindur dapat digunakan menjadi bahan baku edible coating serta berpotensi sebagai bahan yang mampu mempertahankan mutu secara kimia, mikrobiologis dan warna udang kupas sehingga ekstrak buah lindur dapat dijadikan sebagai alternatif bahan antibakteri dan pengawet alami pada udang vannamei kupas.

\section{DAFTAR PUSTAKA}

Abugoch, L.E., Cristián, T., Maria, C.V., Mehrdad, Y.P., \& Mario, D.D. (2011). Characterization of quinoa proteinchitosan blend edible films. J. of Food Hyd. 25: 879886.

[AOAC] Association of Official Analytical Chemistry. (1995). Official Method of Analysis. Association of Official Analytical Chemist AOAC). Published by the Association of Official Analitycal Chemist. Washington DC,USA.

[AOAC] Association of Official Analytical Chemistry. (2006). Edisi revisi. Edisi 18 2005. Official Methods of Analysis the Association of Official Analytical Chemistry, Inc. Washington DC.

Babji, A.S. \& Kee, G.S. (1994). Changes in sarcoplasmic and myofibrillar proteins of spent hen and broiler meat during the processing of surimi-like material (ayami). Pertranika J. Trop Agri Sci. 17(2): 117-123.

Bourbon, A.I., Pinheiro, A.C., Cerqueira, M.A., Rocha, C.M.R., Maria, C., Avides, M.C., Quintas, M.A.C., \& Vicente, A.A. (2011). Physico-chemical characterization of chitosan-based edible films incorporating bioactive compounds of different molecular weight. J. of Food Eng. 106: 111-118.

Bourtoom, T. \& Chinnan, M.S. (2008). Preparation and properties of rice starch-chitosan blend biodegradable film. Food Science and Technology. 41: 1633-1641.

[BSN] Badan Standarisasi Nasional. (2006). Petunjuk Uji Organoleptik Ikan Segar Standar Nasional Indonesia. SNI-01-2346-2006. Standar Nasional Indonesia, Jakarta.

Erdogdu, F., Balaban, M.O., Otwell, W.S., \& Garrido L. (2004). Cook-related yield loss for pacific white (Penaeus vannamei) shrimp previously treated with phosphates: effects of shrimp size and internal temperature distribution. J of Food Eng. 64: 297-300.

Fardiaz, S. (1993). Analisis Mikrobiologi Pangan. Institut Pertanian Bogor. Bogor.

Hargono, Abdullah, \& Sumantri, I. (2008). Production of chitosan is made of the penaeus monodon shell waste and application to serum cholesterol reduction. Reaktor. 12: 53-57.

Hutching, J.B. (1999). Food Color and Appearance. Blackie Academic \& Professional, London.

Kilincceker, O. \& Kurt S. (2009). The sensory quality of pearl mullet (Chalcalburnus tarichi) fillets coated with different coating materials. Turkish J. of Fisheries and Aquatic Sci. 10: 471-476.

Krochta, J. M., Baldwin, E.A. \& Nisperos-Carriedo, M.O. 1994. Edible Coating and Film to Improve Food Quality. Technomic Publ. Co. Inc. Pennsylvania, USA.

López-Caballero, M.E., Gómez-Guillén, M.C., PérezMateos, M., \& Montero, P. (2005). A Chitosan-gelatin blend as a coating for fish patties. J. Food Hyd. 19: 303-311.

Malangngi, L., Meiske, S., \& Jessy P. (2012). Penentuan kandungan tanin dan uji aktivitas antioksidan ekstrak biji buah alpukat (Persea americana mill.). J. MIPA UNSRAT. 1(1): 5-10.

Marliana, E. \& Saleh, C. (2011). Uji fitokimia dan aktivitas antibakteri ekstrak kasar etanol, fraksi n-heksana, etil asetat dan metanol dari buah labu air (Lagenari siceraria (molina) standl). J. Kimia Mulawarman. 8 (2): 63-69.

Rosulva, I., Yadi, H., \& Ema H. (2014). Application of edible coating bases extract of lindur (bruguiera gymnorrhiza) and chitosan on peeled off shrimp. Asian Journal of Agriculture and Food Science. 02(02).

Serdaroglu, M., \& Felekoglu, E. (2005). Effects of using rosemary extract and onion juice on oxidative stability of sardine (Sardina pilchardus) mince. J. Food Qual 28: 109-120.

Sivaperumal, P., Ramasamy, P., Inbaneson, S.J., \& Ravikumar, S. (2010). Screening of antibacterial 
activity of mangrove leaf bioactive compounds against antibiotic resistant clinical isolates. World $\mathrm{J}$ of Fish and Marine Sci. 2(5): 348-353.

Songsaeng, S., Sophanodora, P., Kaewsrithong, J., \& Ohshima, T. (2010). Effect of different storage conditions on quality of white-scar oyster (Crassostrea belcheri). International Food Research J. 17: 491500.

Suptijah, P., Gushagia, \& Sukarsa, D.R. (2007). Kajian efek daya hambat kitosan terhadap kemunduran mutu fillet ikan patin (Pangasius hypothalamus) pada penyimpanan suhu ruang. Buletin Teknologi Hasil Perikanan 11(2):89-101. 